\title{
Efficacy of preoperative testosterone therapy in hypospadias: a systematic review and meta-analysis
}

\author{
Gozali Sembiring ${ }^{1}$ and Yacobda Sigumonrong ${ }^{2^{*}}$
}

\begin{abstract}
Background: Bleeding, hematoma, edema, wound infection, and scar formation are the common problems linked with hypospadias reconstruction. Hormone treatment is recommended before surgical treatment to improve intraoperative circumstances. However, no meta-analysis has explored the effectiveness and side effects of testosterone treatment before surgery in hypospadias.

Main body of the abstract: The purpose of this paperwork is to evaluate the impact of preoperative testosterone treatment in hypospadias based on clinical data from published trials. This study searched MEDLINE, Science Direct, and the Cochrane Library without regard to year. However, only English journals were included, with a manual search using the Preferred Reporting Items for Systematic Reviews and Meta-analysis of Observational Studies in Epidemiology Guidelines supplementing the search. In this meta-analysis, five papers were considered. Two of these investigations were multicenter randomized clinical trials. Two of the studies were prospective, with a median follow-up of varying lengths. A retrospective investigation was conducted. There were 585 patients in all that took part in this trial. After surgery, the complication rate was measured in both the intervention and control groups, including meatal stenosis, fistula, glans dehiscence, scarring, reoperation rate, urethral diverticulum, fine pubic hair, and sexual precocity. The only significant difference between the intervention and control groups was that the intervention group had a decreased frequency of glans dehiscence following surgery (OR 0.40 with the $95 \% \mathrm{Cl}$ of 0.17 until 0.97).

Conclusions: This study discovered that a patient who got testosterone before surgery had a considerably decreased complication risk for glandular dehiscence. Reoperation rate, urethral-cutaneous fistula, meatal stenosis, and penile scarring in children with hypospadias, on the other hand, revealed no significant difference in the testosterone-treated group against the control group.
\end{abstract}

Keywords: Hypospadias, Testosterone, Urethroplasty

\section{Background}

Hypospadias is a congenital penile deformity characterized by an aberrant proximal placement of the urethral meatus on the ventral penis and a lack of ventral foreskin and a curve of the ventral penis $[1,2]$. Bleeding and hemorrhage, edema, wound infection, wound dehiscence, skin and flap

\footnotetext{
* Correspondence: yacobdasigumonrong@yahoo.com

${ }^{2}$ Department of Surgery, Adam Malik General Hospital, University of North

Sumatera, Mongonsidi Street No. 17, Medan, North Sumatra 20351, Indonesia

Full list of author information is available at the end of the article
}

necrosis, penile torsion, penile erection, meatal stenosis, urethral strictures, urethral diverticula, urethral-cutaneous fistulation, and scar formation are all expected consequences of hypospadias restoration [2, 3].

Preoperative hormone treatment with human chorionic gonadotropin (HCG), dihydrotestosterone (DHT), or testosterone $(\mathrm{T})$ was recommended to improve the surgical result of people having hypospadias correction $[2,3]$. Hormone treatment is recommended before surgery to improve intraoperative circumstances $[1,4]$. The 
rationale for using preoperative androgen is that it will promote vascularization of the prepuce, reducing fibrous tissue growth and inflammation. By increasing cutaneous feeding and oxygenation, increased blood flow following surgery can decrease complications and avoid scar formation [2]. Testosterone was successfully used to increase the breadth of the glans by 4.5 $\mathrm{mm}$ in proximal hypospadias newborns with small glans, reducing the incidence of issues associated with small glans size $[1,2,5]$.

However, there is disagreement among researchers about the potential adverse effects of preoperative hormone therapy, such as increased erections, pubic hair formation, faster linear height, and bone aging [6]. Furthermore, androgens were considered to induce inflammation and impede wound healing. According to a new prospective, non-randomized study, hormone stimulation for young hypospadias patients may increase the risk of complications [7]. Furthermore, researchers revealed that $49 \%$ (19 individuals) displayed signs of relative androgen resistance among a sample of hypospadias patients undergoing treatment. As a result of the risk of surgical problems, hormone therapy before hypospadias surgery is a disputed issue with little evidence in the literature to back it up $[1,2]$. In addition, there is much difference in clinical practice when it comes to hormone therapy, whether it is topical or parenteral when administered, and how much it costs $[4,6]$.

As a result, we predicted testosterone preoperative hormonal therapy (PHT) in hypospadias patients not to affect surgical problems. Our meta-analysis looked into and examined several individual studies; the prevalence of surgical complications in hypospadias pediatric patients treated with preoperative topical or intramuscular

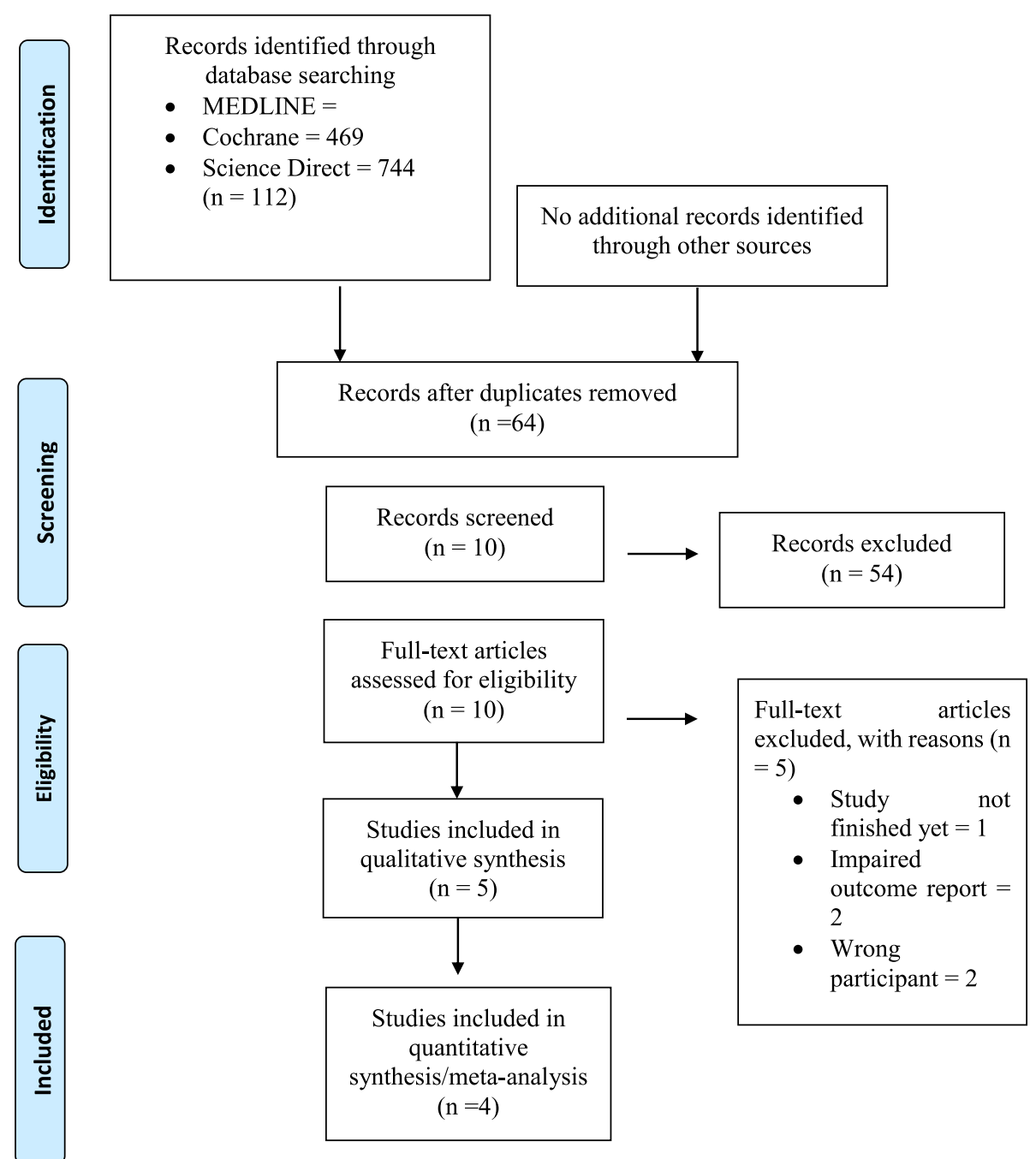

Fig. 1 Study flow diagram 
testosterone was assessed. We are curious if PHT, in addition to testosterone, is required for hypospadias repair.

\section{Methods}

\section{Research question}

Do individuals who get preoperative testosterone therapy for hypospadias have a better outcome and lower risk of adverse events than those who do not get hormonal testosterone treatment?

\section{Types of studies}

Only English papers were considered in this investigation, which comprised randomized control trials, cohort, and case-control studies with no year restrictions. Case studies that lacked comparable groups were omitted. Editorials, comments, and review pieces were not included in the study. Non-peer-reviewed publications (e.g., reports of data from vital statistics, dissertations, or this) were also removed. To avoid duplication of patients from one cohort, we chose one study for each of our analyses based on a hierarchical assessment of the comparability of research groups and time of research (priority for more recent), and multiple individuals when there was more than one publication originating from the same patient cohort (Supplementary data).

\section{Types of participants and exposure}

This study looked at studies that looked at boys diagnosed with hypospadias as the primary diagnosis and patients who had been exposed to some hormone stimulation preoperatively or postoperatively, surgical correction, postoperative sequelae, and clinical research designation. The review examined all sorts of studies. The English language was utilized as a criterion for eligibility.

\section{Outcome measures}

Complications and adverse effects following surgery are the key outcomes. According to the original research included, any recorded variation from the typical postoperative course is characterized. In our statistical analysis, all problems were given equal weight, and patients were

Table 1 Characteristics of the included studies

\begin{tabular}{|c|c|c|c|c|c|c|c|c|c|}
\hline \multirow[t]{2}{*}{ Authors } & \multirow{2}{*}{$\begin{array}{l}\text { Publication } \\
\text { year }\end{array}$} & \multirow{2}{*}{$\begin{array}{l}\text { Study } \\
\text { design }\end{array}$} & \multicolumn{2}{|c|}{ Sample size } & \multirow{2}{*}{ Population } & \multirow{2}{*}{$\begin{array}{l}\text { Mean } \\
\text { age }\end{array}$} & \multirow[t]{2}{*}{ Intervention } & \multirow[t]{2}{*}{ Exclusion criteria } & \multirow{2}{*}{$\begin{array}{l}\text { Follow- } \\
\text { up }\end{array}$} \\
\hline & & & $\begin{array}{l}\text { Study } \\
\text { group }\end{array}$ & $\overline{\text { Controls }}$ & & & & & \\
\hline $\begin{array}{l}\text { Rynja } \\
\text { et al. }\end{array}$ & 2017 & $\begin{array}{l}\text { Retrospective } \\
\text { study }\end{array}$ & 34 & 87 & $\begin{array}{l}\text { Adult men } \\
\text { operated for } \\
\text { hypospadias in } \\
\text { childhood }\end{array}$ & $\mathrm{N} / \mathrm{A}$ & $\begin{array}{l}\text { Topical cream } 5 \% \text { twice a } \\
\text { day during two periods of } \\
14 \text { days (separated by } 1 \\
\text { week). Intramuscular } \\
\text { therapy: } 25 \text { m Sustanon } \\
\text { per week for } 2-3 \text { weeks. }\end{array}$ & $\begin{array}{l}\text { Incorrect contact } \\
\text { details, patients } \\
\text { referred for redo } \\
\text { hypospadias repair }\end{array}$ & $\mathrm{N} / \mathrm{A}$ \\
\hline $\begin{array}{l}\text { Babu } \\
\text { et al. }\end{array}$ & 2018 & $\begin{array}{l}\text { Prospective } \\
\text { study }\end{array}$ & 94 & 92 & $\begin{array}{l}\text { Patients with } \\
\text { distal } \\
\text { hypospadias }\end{array}$ & $\begin{array}{l}15.3 \\
(1.0) \\
\text { months } \\
\text { and } \\
13.4 \\
(1.1) \\
\text { months }\end{array}$ & $\begin{array}{l}\text { Study group: three doses } \\
\text { of intramuscular } \\
\text { testosterone enanthate } 2 \\
\text { mg/kg at the age of } 9,10 \text {, } \\
\text { and } 11 \text { months. Controls } \\
\text { did not receive any } \\
\text { intervention. }\end{array}$ & N/A & $\begin{array}{l}\text { Over } 4 \\
\text { years }\end{array}$ \\
\hline $\begin{array}{l}\text { Asgari } \\
\text { et al. }\end{array}$ & 2015 & $\begin{array}{l}\text { Randomized } \\
\text { controlled } \\
\text { trial }\end{array}$ & 91 & 91 & $\begin{array}{l}\text { Children with } \\
\text { primary distal } \\
\text { and mid-shaft } \\
\text { hypospadias } \\
\text { who under- } \\
\text { went surgical } \\
\text { repair }\end{array}$ & $\begin{array}{l}30 \\
\text { months }\end{array}$ & $\begin{array}{l}\text { Study group: } 2 \mathrm{mg} / \mathrm{kg} \\
\text { intramuscular testosterone } \\
\text { enanthate once per month } \\
\text { for } 2 \text { months pre- } \\
\text { operatively. }\end{array}$ & $\begin{array}{l}\text { Previous history of } \\
\text { hypospadias repair } \\
\text { and any proven } \\
\text { endocrine disorder }\end{array}$ & $\begin{array}{l}3 \\
\text { months }\end{array}$ \\
\hline $\begin{array}{l}\text { Nerli } \\
\text { et al. }\end{array}$ & 2008 & Prospective & 10 & 11 & $\begin{array}{l}\text { Children with } \\
\text { micro phallic } \\
\text { hypospadias }\end{array}$ & $\mathrm{N} / \mathrm{A}$ & $\begin{array}{l}\text { Topical vs. parenteral } \\
\text { testosterone prior to } \\
\text { surgery. }\end{array}$ & Not stated & 1 year \\
\hline $\begin{array}{l}\text { Kaya } \\
\text { et al. }\end{array}$ & 2007 & $\begin{array}{l}\text { Randomized } \\
\text { controlled } \\
\text { trial }\end{array}$ & 37 & 38 & $\begin{array}{l}\text { Children with } \\
\text { primary } \\
\text { hypospadias }\end{array}$ & $\begin{array}{l}33.4 \pm \\
3.7\end{array}$ & $\begin{array}{l}\text { Study group: application of } \\
2.5 \% \text { DHT transdermal gel } \\
\text { directly onto the penile } \\
\text { shaft and glans once daily } \\
\text { before bedtime for } 3 \\
\text { months. DHT gel: } 0.2 \text { to } \\
0.3 \mathrm{mg} / \mathrm{kg} \text { body weight. } \\
\text { Controls did not receive } \\
\text { treatment. }\end{array}$ & $\begin{array}{l}\text { Children with } \\
\text { endocrinological or } \\
\text { clinical evidence of } \\
\text { hypopituitarism and } \\
\text { children with a } \\
\text { history of } \\
\text { hypospadias surgery }\end{array}$ & $\begin{array}{l}\text { 1-year } \\
\text { follow- } \\
\text { up }\end{array}$ \\
\hline
\end{tabular}




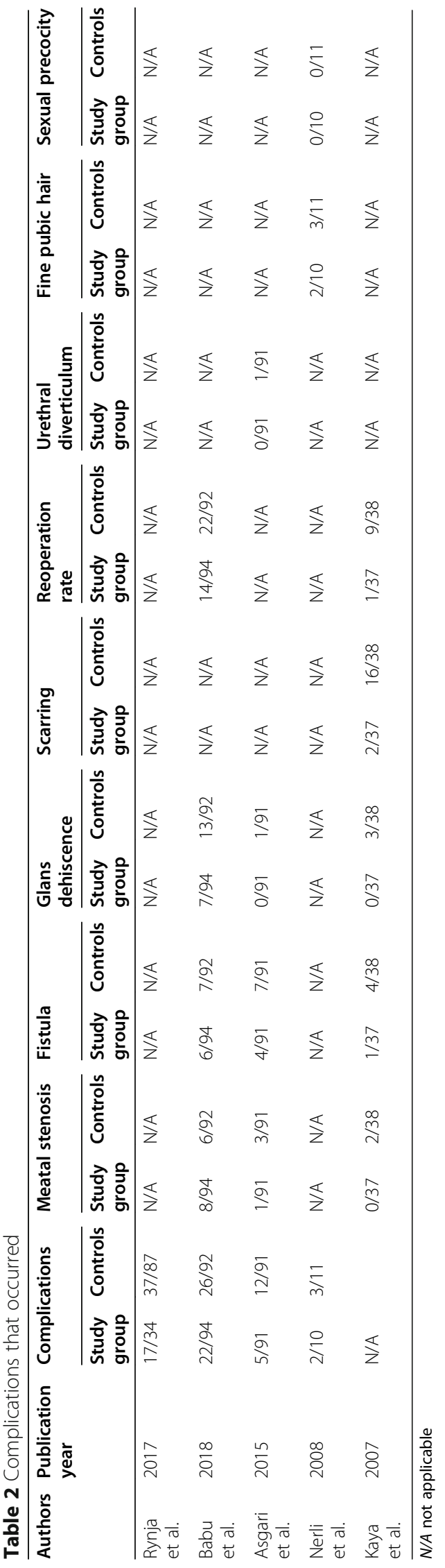




\section{As percentage (intention-to-treat)}

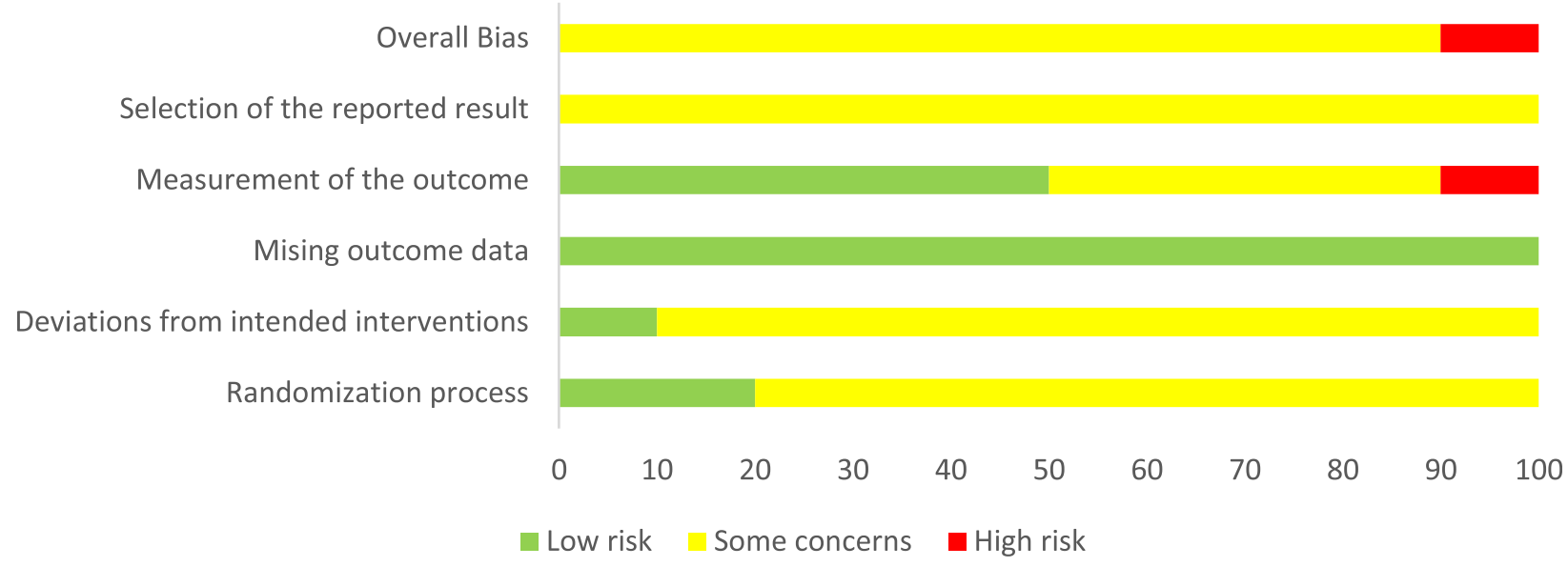

Fig. 2 Risk of bias of the included studies illustrated in percentage

classified as having or not having a problem based on the information provided in each report.

\section{Method of review}

The techniques of analysis and inclusion criteria for this investigation were outlined in advance in a protocol. The Population, Intervention, Control, Outcome, Study Design (PICOS) technique sets the inclusion criteria during the literature search. Only papers on boys with hypospadias as the significant diagnosis were included. A comprehensive literature search was carried out in August 2018 in the following databases: MEDLINE, Cochrane CENTRAL, and Science Direct with the keyword hypospadias and testosterone therapy. A thorough search method was utilized to conduct the literature search. For reporting this systematic review and meta-analysis, the Preferred Reporting Items for Systematic Review and MetaAnalysis of Observational Studies in Epidemiology (PRISMA) standards were utilized (Fig. 1).

\section{Result}

\section{Literature search results}

A preliminary search turned up 112 probable literature citations, including 32 from PubMed, two from the Cochrane Library, 26 from EMBASE, and 52 from ISI Web of Science. Due to duplicate research, 78 studies were removed. Following elimination at the title and abstract phases, ten possibly relevant papers were identified and retrieved for a full-text assessment based on the predefined selection criteria. One article was a duplication, one was an editorial, one research employed different therapy, and three others had the wrong outcome, did not seek to compare, and were duplicating. Finally, five papers were found to be appropriate for inclusion in this analysis.

\section{Study characteristics}

The research characteristics and methods of the five studies included in the meta-analysis are shown in Table 1. Two of these studies were multi-center randomized clinical trials [1-5]. Two of the studies were

\begin{tabular}{|c|c|c|c|c|c|c|c|c|c|c|}
\hline Study or Subgroup & $\begin{array}{l}\text { Experim } \\
\text { Events }\end{array}$ & $\begin{array}{l}\text { ental } \\
\text { Total }\end{array}$ & $\begin{array}{l}\text { Contr } \\
\text { Events }\end{array}$ & $\begin{array}{l}\text { ol } \\
\text { Total }\end{array}$ & Weight & $\begin{array}{c}\text { Odds Ratio } \\
\text { M-H, Fixed, } 95 \% \mathrm{Cl}\end{array}$ & & $\begin{array}{r}\text { Odds F } \\
\text { M-H, Fixed }\end{array}$ & $\begin{array}{l}\text { Ratio } \\
\text { d, } 95 \% \mathrm{Cl}\end{array}$ & \\
\hline Asgari et al & 5 & 91 & 12 & 91 & $25.7 \%$ & $0.38[0.13,1.14]$ & & $\longrightarrow-2$ & & \\
\hline Babu et al & 22 & 94 & 26 & 92 & $45.6 \%$ & $0.78[0.40,1.50]$ & & $\longrightarrow$ & E & \\
\hline Nerli et al & 2 & 10 & 3 & 11 & $5.2 \%$ & $0.67[0.09,5.13]$ & & $\cdot 1$ & & \\
\hline Rynja et al & 17 & 34 & 37 & 87 & $23.5 \%$ & $1.35[0.61,2.99]$ & & & $F$ & \\
\hline Total $(95 \% \mathrm{Cl})$ & & 229 & & 281 & $100.0 \%$ & $0.80[0.52,1.25]$ & & & & \\
\hline Total events & 46 & & 78 & & & & & & & \\
\hline \multicolumn{7}{|c|}{$\begin{array}{l}\text { Heterogeneity: } \mathrm{Chi}^{2}=3.47, \mathrm{df}=3(\mathrm{P}=0.32) ; \mathrm{I}^{2}=14 \% \\
\text { Test for overall effect: } \mathrm{Z}=0.96(P=0.33)\end{array}$} & ${ }_{\mathrm{F}}^{0.01}$ & 0.1 s [experimental] & $\begin{array}{c}10 \\
\text { Favours [control] }\end{array}$ & 100 \\
\hline
\end{tabular}




\begin{tabular}{|c|c|c|c|c|c|c|c|c|c|}
\hline \multirow{2}{*}{$\begin{array}{l}\text { Study or Subgroup } \\
\text { Asqari et al }\end{array}$} & Experimental & $\begin{array}{l}\text { ental } \\
\text { Total }\end{array}$ & Control & $\begin{array}{l}\text { ol } \\
\text { Total }\end{array}$ & Weight & \multirow{2}{*}{$\begin{array}{c}\begin{array}{c}\text { Odds Ratio } \\
\text { M-H, Fixed, 95\% Cl }\end{array} \\
0.33[0.03,3.19]\end{array}$} & \multicolumn{3}{|c|}{$\begin{array}{c}\text { Odds Ratio } \\
\text { M-H, Fixed, } 95 \% \mathrm{Cl}\end{array}$} \\
\hline & 1 & 91 & 3 & 91 & $27.1 \%$ & & $\because$ & & \\
\hline Babu et al & 8 & 94 & 6 & 92 & $50.7 \%$ & $1.33[0.44,4.01]$ & & 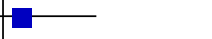 & \\
\hline Kaya et al & 0 & 37 & 2 & 38 & $22.2 \%$ & $0.19[0.01,4.20]$ & $\leftarrow$ & & \\
\hline Total $(95 \% \mathrm{Cl})$ & & 222 & & 221 & $100.0 \%$ & $0.81[0.33,1.96]$ & & & \\
\hline Total events & 9 & & 11 & & & & & & \\
\hline $\begin{array}{l}\text { Heterogeneity: } \mathrm{Chi}^{2}= \\
\text { Test for overall effect }\end{array}$ & $\begin{array}{l}2.23, \mathrm{df}= \\
Z=0.47\end{array}$ & $\begin{array}{l}2(P= \\
(P=0.6\end{array}$ & $\begin{array}{l}0.33) ; 1^{2} \\
64)\end{array}$ & $=10 \%$ & & & $\begin{array}{lll}0.01 & 0.1 & 1 \\
& \text { Favours [experimental] }\end{array}$ & 10 & 100 \\
\hline
\end{tabular}

prospective studies with varying follow-up times [510]. A retrospective investigation was conducted. There were a total of 585 patients in this trial.

\section{Measurement of outcome}

We considered studies that assessed hypospadias using any of the known and validated tools. Patients in the research were given testosterone (parenteral, intramuscular, and intradermal) daily, with follow-up modifications. The complication rate following treatment, such as meatal stenosis, fistula, glans dehiscence, scarring, reoperation rate, urethral diverticulum, fine pubic hair, and sexual precocity, was the result that was measured. Table 2 shows the rate of complications.

\section{Meta-analysis result}

The forest plot of the complication rate in the selected studies is depicted in Fig. 2. $I^{2}$ values of $14 \%$ show that the studies are homogeneous. In this forest plot, the analysis is carried out using the fixed-effect model. With a $95 \%$ confidence interval of 0.52 to 1.25 , the odds ratio is 0.80 . To summarize, there is no statistically significant difference in the complication rate between the experimental and control groups.

Figure 3 shows a forest plot of meatal stenosis. The investigations are homogeneous $\left(I^{2}\right.$ statistics of $\left.10 \%\right)$, and they were carried out in the forest plot using the fixedeffect model. There are no significant changes between the patients and the control group, according to this forest plot. The odds ratio is 0.8 , with a confidence range of 0.33 to 1.96 , as shown.
Figure 4 shows the sole significant difference between the experimental and control groups in this research. These investigations on glans dehiscence following DHT therapy are all consistent. With a 95\% confidence interval of 0.17 to 0.97 , the odds ratio is 0.40 .

The forest plot of the fistula in the included studies is depicted in Fig. 5. The $I^{2}$ statistics of $0 \%$ imply that the studies are homogeneous. In this forest plot, the analysis is carried out using the fixed-effect model. With a $95 \%$ confidence interval of 0.27 to 1.27 , the odds ratio is 0.59 . To summarize, there is no significant difference in fistula development between the experimental and control groups.

The reoperation rate is depicted in Fig. 6 as a forest plot. The experiments are homogeneous ( $I^{2}$ statistics of $10 \%)$, and they were carried out in a forest plot using a fixed-effect model. There are no significant changes between the patients and the control group, according to this forest plot. The odds ratio is 0.29 , with a confidence range of 0.05 to 1.67 , as shown. Figure 7 shows the same finding in terms of complication: there is no significant difference between the experimental and control groups in this investigation (Fig. 8). We have not conducted a funnel plot analysis since the studies included in this study were less than ten studies.

\section{Discussion}

One of the most frequent male genital abnormalities is hypospadias. Hypospadias is becoming more common [8]. Hypospadias surgery aims to rebuild the urethra from the tip of the glans to an excellent esthetic outcome. Glans dehiscence, urethral-cutaneous fistula,

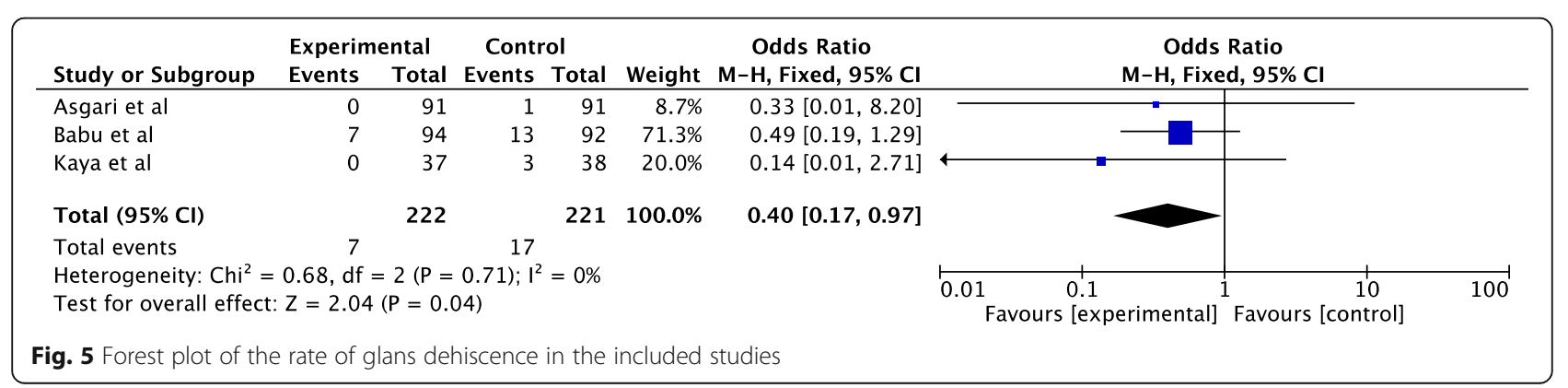




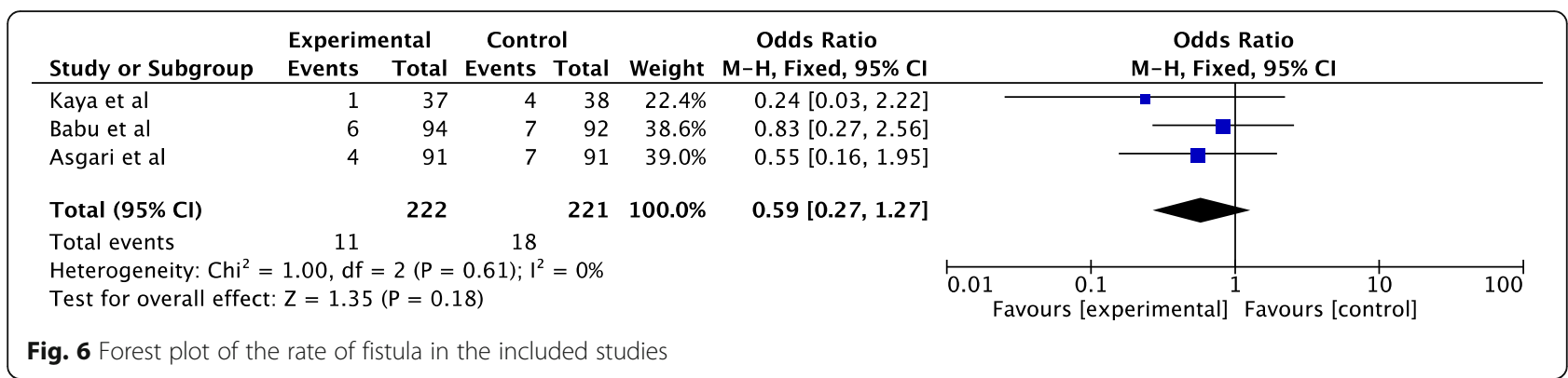

meatal stenosis, and penile scarring are all consequences of the operation. Hormonal stimulation before surgery is something that has been done for decades [9]. Testosterone has been utilized to do more research. The usage of testosterone, however, is still debatable. There is no recognized standard process at this time.

In order to improve surgical outcomes, androgen stimulation can be used. Androgen stimulation is thought to increase phallic development, making surgical correction more straightforward [10]. Furthermore, androgen stimulation has resulted in fewer problems. Androgen stimulation (testosterone, dihydrotestosterone, and human chorionic gonadotropin) has been shown to enhance the penile length, glans circumference, and tissue vascularity in previous research [11].

Hypospadias surgery is a complex surgery that involves several variables, namely anatomical variations, tissue handling, surgical technique, suture material, and stenting. As a result, it is difficult to compare the complication rates. According to the study, the patients received various surgical repair approaches, including OIF, TIP, Koyanagi urethroplasty, 2-stage repair, and buccal mucosa transplant repair [12].

Androgen stimulation has been suggested as a way to enhance surgical outcomes. The results of the pooled research, on the other hand, indicated that there might be a link between hormone usage and higher complication rates in patients with severe hypospadias. It might be due to a selection bias. The bias might be related to the fact that some of the individuals who were given hormone therapy had some of the most severe anatomical abnormalities and unfavorable tissue features [13].
Kaya et al. randomized 75 infants with primary hypospadias to either have a daily application of $2.5 \%$ DHT for 3 months before surgery or to have TIP hypospadias correction without pretreatment. Compared to a control group, the DHT group had a considerably decreased complication rate (glandular dehiscence, fistulas) and reoperation rate. Patients who received DHT therapy had fewer reoperations for fistulas ( 1 vs. $4, P>0.05$ ), glandular dehiscence ( 0 vs. 3, P0.05), and meatal stenosis (0 vs. $2, P>0.05)$ than patients who did not get DHT treatment [14].

According to the study, DHT pretreatment improved penile cosmesis (moderate-to-severe scarring in 2 patients in the treatment group vs. 16 patients in the notreatment group). Scar formation after hypospadias treatment is a critical criterion for cosmesis assessment. It was found to be significantly lower in DHT-treated children than in the control group. This measure is considered relevant due to the recognized importance of psychological satisfaction and the development of selfesteem later in life. According to the study, pretreatment with DHT transdermal gel reduces complication and reoperation rates after hypospadias repair while also improving esthetic outcomes [15].

Gorduza et al. used monthly intramuscular injections, stopping when the penile length reached or surpassed $35 \mathrm{~mm}$. According to the study, patients who had therapy less than 3 months before surgery had a significantly higher complication risk ( $50 \%$ fistula rate) than those who had therapy more than 3 months before surgery (26.3\%, $P>0.34)$. The period between hormonal stimulation and the surgery and the scheduling of hormonal

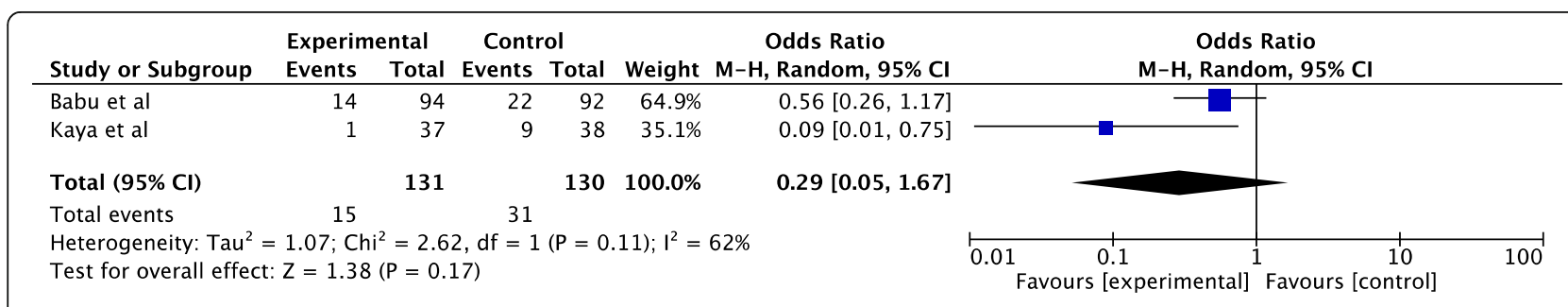

Fig. 7 Forest plot of reoperation rate in the included studies 


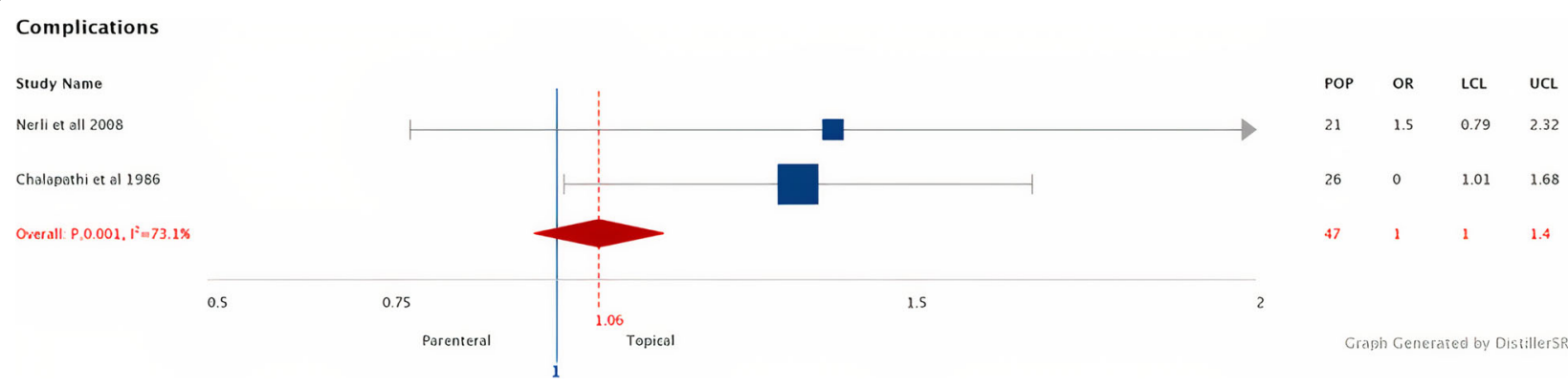

Fig. 8 Forest plot of complication of testosterone administration

treatment may have influenced surgical outcomes. As a result, the results of this study cannot be used as a comparison point or to make therapeutic recommendations [16].

According to Babu and Chakravarthi, preoperative testosterone significantly increases glans width and reduces difficulties and the necessity for reoperation as well. It also raises parental satisfaction and the appearance of the child. Group 2b had much fewer issues (17.9\%) than group $2 \mathrm{a}(50 \%)$. The reoperation rate in group $2 \mathrm{~b}$ (11.5\%) was much lower than in group 1 (excluding those with minor glans dehiscence treated conservatively or meatal stenosis treated without patient dilation) (23.1\%) [17].

Studies that did not show a significant difference in penile length found that topical usage was related with more genital pigmentation, pubic hair development, and skin irritation at the application site, suggesting that intramuscular hormone treatment is preferred than topical therapy [18].

Because topical medicines are not absorbed via the gastrointestinal system and do not undergo first pass hepatic metabolism, they are associated with more minor side effects [19]. On the other hand, injections of parenteral hormones might make it difficult for parents to comply, especially if the injection is not suggested. A bad early injection experience has been shown to increase anxiety in children, making the subsequent injection experience worse. After 3 months, the transdermal DHT gel's adverse effects were minimal [20]. There were just a few complaints of uncomfortable feelings on the penile skin in other teenagers. One-third of our patients had transient pruritus, erythema, and darkening of the penile skin that disappeared after the medicine was stopped [21].

When it comes to intraoperative and postoperative difficulties, the literature is not always uniform in how they are characterized. The lack of considerable, difficult-tocontrol bleeding was mentioned in the studies that stated there were no intraoperative complications [22].

\section{Conclusion}

We discovered a much decrease complication rate for glandular dehiscence in this trial. Reoperation rate, urethral-cutaneous fistula, meatal stenosis, and penile scarring in children with hypospadias, on the other hand, demonstrated that there was no significant difference in the result or side effects in the group receiving testosterone therapy compared to the control group in terms of method of administration (parenteral or topical).

\section{Abbreviation}

PHT: Preoperative hormonal therapy; DHT: Dihydrotestosterone; HCG: Human chorionic gonadotropin; TIP: Tubularized incised plate

\section{Supplementary Information}

The online version contains supplementary material available at https://doi. org/10.1186/s43159-021-00117-4.

\section{Additional file 1. APPENDICES}

\section{Acknowledgements}

I would like to express my very great appreciation to Dr. Yacobda for his valuable and constructive suggestions during the planning and development of this research work. His willingness to give his time so generously has been very much appreciated.

\section{Authors' contributions}

There are 2 authors who contributed to this paperwork: GS who contributed to the concept and structure of this paperwork. YS contributed to the whole concept of this paperwork. All authors have read and approved the final manuscript.

\section{Funding}

The source of funding of this paper is solely from the authors.

Availability of data and materials

All data generated or analyzed during this study are included in this published article.

\section{Declarations}

Ethics approval and consent to participate Not applicable.

Consent for publication Not applicable. 


\section{Competing interests}

The authors declare that they have no competing interests.

\section{Author details}

'University of Indonesia, Adam Malik General Hospital, Bunga Lau Street No. 18, Medan, North Sumatra 20135, Indonesia. ${ }^{2}$ Department of Surgery, Adam Malik General Hospital, University of North Sumatera, Mongonsidi Street No.

17, Medan, North Sumatra 20351, Indonesia.

Received: 12 June 2021 Accepted: 9 July 2021

Published online: 09 November 2021

\section{References}

1. Göllü Bahadır G, Ergün E, Telli O, Khanmammadov F, Çakmak AM. Hormone therapy in hypospadias surgery: a survey on the current practice in Turkey. (1300-0144 (Print))

2. Chao M, Zhang Y, Liang C. Impact of preoperative hormonal stimulation on postoperative complication rates after hypospadias repair: a meta-analysis. (1827-1758 (Electronic)).

3. Wong NC, Braga LH. The influence of pre-operative hormonal stimulation on hypospadias repair. (2296-2360 (Print)).

4. Bastos AN, Oliveira Lr Fau-Ferrarez CEPF, Ferrarez Ce Fau-de Figueiredo AA de Figueiredo Aa Fau-Favorito LA, Favorito La Fau-Bastos Netto JM, Bastos Netto JM. Structural study of prepuce in hypospadias--does topical treatment with testosterone produce alterations in prepuce vascularization? (1527-3792 (Electronic)).

5. Asgari SA, Safarinejad MR, Poorreza F, Asl AS, Ghanaie MM, Shahab E. The effect of parenteral testosterone administration prior to hypospadias surgery: a prospective, randomized and controlled study. (1873-4898 (Electronic)).

6. Netto JM, Ferrarez Ce Fau - Schindler Leal AA, Schindler Leal Aa Fau - Tucci S, Jr., Tucci S Jr Fau - Gomes CA, Gomes Ca Fau - Barroso U, Jr., Barroso U, Jr. Hormone therapy in hypospadias surgery: a systematic review. (18734898 (Electronic)).

7. Malik RD, Liu DB. Survey of pediatric urologists on the preoperative use of testosterone in the surgical correction of hypospadias. (1873-4898 (Electronic)).

8. Ahmeti H, Kolgeci S, Arifi H, Jaha L. Clinical dilemmas and surgical treatment of penoscrotal, scrotal and perineal hypospadias. Bosnian Journal of Basic Medical Sciences. 2009;9(3):229-34. https://doi.org/10.17305/ bjbms.2009.2812.

9. Monfort G, Fau-Lucas C, Lucas C. Dehydrotestosterone penile stimulation in hypospadias surgery. (0302-2838 (Print)).

10. Gearhart JP, Jeffs RD. The use of parenteral testosterone therapy in genital reconstructive surgery. (0022-5347 (Print)).

11. Ahmad R, Chana RS, Ali SM, Khan S. Role of parenteral testosterone in hypospadias: a study from a teaching hospital in India. Urology Annals. 2011:3(3):138-40. https://doi.org/10.4103/0974-7796.84966.

12. Wright I, Cole E Fau-Farrokhyar F, Farrokhyar F, Fau-Pemberton J, Pemberton J Fau-Lorenzo AJ, Lorenzo Aj Fau-Braga LH, Braga LH. Effect of preoperative hormonal stimulation on postoperative complication rates after proximal hypospadias repair: a systematic review. (1527-3792 (Electronic)).

13. Kaya C, Radmayr $C$. The role of pre-operative androgen stimulation in hypospadias surgery. Translational Andrology and Urology. 2014;3(4):340-6. https://doi.org/10.3978/j.issn.2223-4683.2014.12.01.

14. Kaya C, Bektic J Fau-Radmayr C, Radmayr C, Fau-Schwentner C, Schwentner C, Fau-Bartsch G, Bartsch G, Fau-Oswald J, Oswald J. The efficacy of dihydrotestosterone transdermal gel before primary hypospadias surgery: a prospective, controlled, randomized study. (1527-3792 (Electronic)).

15. Kaplan GW. Does administration of transdermal dihydrotestosterone gel before hypospadias repair improve postoperative outcomes? (1743-4289 (Electronic)).

16. Gorduza DB, Gay Cl Fau-de Mattos E Silva E, de Mattos E Silva E FauDemède $D$, Demède D, Fau-Hameury F, Hameury F, Fau-Berthiller J, Berthiller J Fau-Mure P-Y, et al. Does androgen stimulation prior to hypospadias surgery increase the rate of healing complications? - a preliminary report. (1873-4898 (Electronic)).

17. Babu R, Chakravarthi $\mathrm{S}$. The role of preoperative intramuscular testosterone in improving functional and cosmetic outcomes following hypospadias repair: a prospective randomized study. (1873-4898 (Electronic)).
18. Chalapathi G, Rao Kl Fau-Chowdhary SK, Chowdhary Sk Fau-Narasimhan KL, Narasimhan KI Fau-Samujh R, Samujh R Fau-Mahajan JK, Mahajan JK. Testosterone therapy in microphallic hypospadias: topical or parenteral? (1531-5037 (Electronic)).

19. Sakakibara N, Nonomura K Fau-Koyanagi T, Koyanagi T, Fau-Imanaka K, Imanaka K. Use of testosterone ointment before hypospadias repair. (0042 1138 (Print)).

20. Krishnan A, Chagani S, Rohl AJ. Preoperative testosterone therapy prior to surgical correction of hypospadias: a review of the literature. Cureus. 2016 8(7):e677-e.

21. Wong NC, Braga LH. The influence of pre-operative hormonal stimulation on hypospadias repair. Front Pediatr. 2015;3:31.

22. Bhat A, Bhat M, Kumar V, Kumar R, Mittal R, Saksena G. Comparison of variables affecting the surgical outcomes of tubularized incised plate urethroplasty in adult and pediatric hypospadias. (1873-4898 (Electronic))

\section{Publisher's Note}

Springer Nature remains neutral with regard to jurisdictional claims in published maps and institutional affiliations.

\section{Submit your manuscript to a SpringerOpen ${ }^{\circ}$ journal and benefit from:}

- Convenient online submission

- Rigorous peer review

- Open access: articles freely available online

- High visibility within the field

- Retaining the copyright to your article

Submit your next manuscript at $\boldsymbol{\nabla}$ springeropen.com 